\title{
Harnessing Science and Technology Research Results to Diversify the Nigerian Economy Through Science Governance Project Ogodometirics International (POI) WSSD +22 in Songhai-Delta, Amukpe-Sapele, Delta State, Nigeria
}

\author{
Ogodo, A.D. \\ Department of Science Laboratory Technology \\ Delta State Polytechnic \\ Ogwashi-Uku, Delta State, Nigeria. \\ E-mail: dicksonogodo@yahoo.com \\ Phone: +2348030738401
}

\begin{abstract}
In this present Globalized World, Science and Technology is the benchmark on which national progress and development is measured. This scientific research work clearly reveals that no Nation can be competitive in the modern world without properly harnessing and developing its Science and Technology potentials. The research work shows that Nigeria's current ranking in the world makes Nigerian Vision (NV) 20:2020 look bleak or totally impossible hence we extend the horizon of targeted socio-economic might to match the Global Sustainable Development Goal (SDG) 2030 to which many countries currently align. The research emphasizes that Central Intelligence Agency (CIA) World Fact book ranked Nigerian as the 41st on the list of development economies based on Gross Domestic Product (GDP) for 2007. For the same year, World Bank ranked Nigeria 40th on the Group Description of Knowledge Index. Nigeria ranked 66th among the Lagging Followers Group. On Global Competitiveness ranking, Nigeria ranked 95th. This research dwells extensively and specifically on the way forward (Science Governance) through Project Ogodometirics International (POI) WSSD +22 in Songhai-Delta, Amukpe-Sapele, Delta State, Nigeria by investing in Advanced Manufacturing Technologies (AMT) which made the Chinese to become the fourth growth zone along with the U.S, Japan and Germany. The research expresses the beliefs that though it took Britain 58 years to double its Per Capital Output, China has been doing it every 7 years in the last 2 decades by thinking and doing things differently. The research concludes that Science and Technology can diversify the Nation Economy through one strategy of Emerging Technologies Project Ogodometrics International (POI) WSSD +22 in Songhai-Delta, Amukpe-Sapele, Delta State, Nigeria. The research recommends that a Scientific/Technical Adviser under the Presidency is the only option for Nigeria using Science Governance of Project Ogodometrics International (POI) WSSD +22 in Songhai-Delta, AmukpeSapele, Delta State, Nigeria in order to facilitate the required synergy to realize the nexus between Science and the National economy to bring 154 International Standards Organization (ISO) Countries to Songhai-Delta, AmukpeSapele, Delta State, Nigeria to sign a MOU with the Nigerian Government via Final Investment Decision (FID) of Technology Transfer Agreement (TTA) of Ogodo Intellectual Property Rights (OIPR).
\end{abstract}

Keywords: Science and Technology/National Economy/Science Governance (Presidency), Project Ogodometrics International (POI)/Ogodo Intellectual Property Rights (OIPR); International Standards Organization (ISO) Countries/Final Investment Decision (FID)/MOU)/ Songhai-Delta, Amukpe-Sapele, Delta State, Nigeria. Pp 167-194 www.isteams.net/ghana2021. DOI - https://doi.org/ 10.22624/AIMS/iSTEAMS-2021/V27P15 


\section{INTRODUCTION}

The History of our Nation is replete with great Scientific and Technological innovations that have been recognized in modern history. We take pride in our historical strides in Arts, Culture, Traditional Medicine, Meteorology, Agriculture, to mention but a few. The accomplishments by our people were underpinned in Science and Technology, a service tool that has supported the advancement of man over the years. Science, Technology and Innovation (ST\&I) remain the key tool that will help us to achieve the desired transformation. The resources of our people stem from the gains of the application of the output of Science, Technology and Innovation in other Countries and the implication for the quick turn-around of the economy. The National Science, Technology and Innovation (ST\&I) Policy is not only for the Federal Ministry of Science and Technology (FMST) and its agencies, but also as platform for collaboration among agencies of Federal and State Ministries. The Federal Ministry of Science and Technology (FMST) is a Service Ministry of Government and as such, has the mandate to interact with all relevant Agencies and Organisations, synergizing and promoting the application of ST\&I results in all sections of the economy.

His Excellency, Muhammadu Buhari, President and Commander-in-Chief of the Armed Forces, Federal Republic of Nigeria being the Current Chairman of the National Research and Innovation Council (NRIC) will provide the leadership needed by the Science, Technology and Innovation (ST\&I) Policy to drive our national development on all fronts while preserving and respecting the individual mandates and responsibilities of the Line Ministries and Agencies of Government.

The Leadership of the Federal Ministry of Science and Technology is being commended for the production of the National Science, Technology and Innovation Policy documents, which seeks to transform the vision of our Founding fathers into reality and this had led to enhance the status of our beloved Country among the Comity of Nations and sustain our pride of place as Giant of the African continent (Jonathan, 2012).

The global economic landscape is experiencing rapid changes. Globalization especially is creating new opportunities and new challenges. Its impact on national economies is driven by significant progress in Science and Technology (S \& T) as exemplified by a plethora of breakthroughs in Biotechnology, Space Research, Energy Development, and Information and Communication Technology (ICT), among others. It is therefore obvious that if Nigeria, given its natural endowments, is to successfully transform its economy and take her rightful place in the Comity of nations, S\&T and its integration in national socio-economic development processes must be accorded the highest priority. It is in this regard that the Transformation Agenda of the Former President, Goodluck Jonathan's Administration which calls for a fundamental and far-reaching reorientation of the Nigerian State towards holistic socio-economic development in the framework of Vision 20:2020 must be understood.

In Nigeria, various administrations since independence showed interests and increased appreciation of the role of S\&T in national socio-economic development. The realization of this fact motivated the Federal Government to re-establish the Federal Ministry of Science and Technology (FMST) as a separate entity in 1985. Nigeria has expended a great deal of effort on S\&T policy development through a combination of the untiring efforts of its Scientists, Engineers and Technologists, International Cooperation and Government Support. The First National Science and Technology Policy in the Country was produced in 1986. The policy was designed to create harmony in the pursuit of knowledge about the environment through Research and Development (R\&D). The aim was to use S\&T knowledge to ensure a better quality of life for the people. 


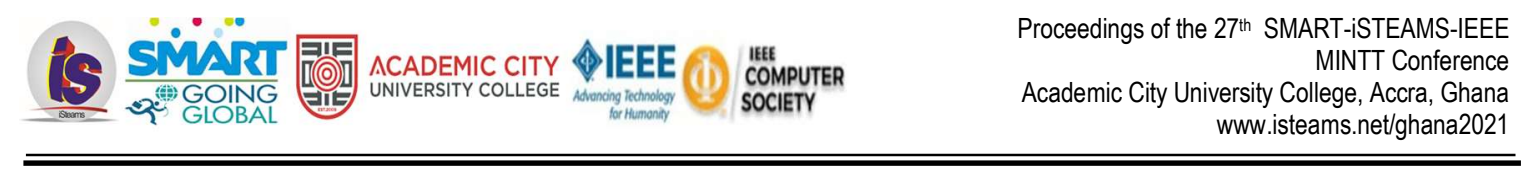

The Policy was reviewed in 1997 to give more emphasis to Co-ordination and Management of S\&T system, Sectoral Developments, Collaboration and Funding. In 2003, the S\&T Policy underwent yet another review to take account of lapses observed in the implementation of the 1997 policy especially on the need to address the institutional frameworks that should foster interaction among the various elements of the National Innovation Systems (NIS). The review also incorporated a programmatic approach to Policy formulation. It emphasized the need for a coherent, systematic and comprehensive approach to the determination of Technological Programmes. The policy gave prominence to Flagship Programmes of Government of the day such as Biotechnology, Information and Communication Technology (ICT), Space Science and Technology, Energy and Engineering Materials e.t.c.

However, the 2003 "Policy" Document is now seen as a compendium of key S\&T sub-sectoral policies, and rather voluminous. Furthermore, it did not adequately attend to the issue of $S \& T$ culture and the harmonization of S\&T policy with other socio-economic policies.In 2005, the need to carry out a system-wide reform was consummated and implemented under the Nigeria/UNESCO Science, Technology and Innovation (ST\&I) reform initiative. It adopted the National Innovation System approach as a framework for Science, Technology and Innovation (ST\&I) system reform. The reform, among other issues, stressed that economic development initiatives, Institutional Governance, Research and Development agenda for the Country, Funding Mechanisms, Intellectual Property (IP) and ST\&I infrastructure development be addressed in any new policy that would address these challenges became indispensable.

The new ST\&I Policy, taking advantage of the experiences in the design and implementation of S\&T Policy in the last two decades and a half, is a product of a novel, all-inclusive, participatory Policy making; involving Consultative meetings with various Stakeholders across the length and breath of the Country as well as International Development Partners. The participatory approach to the design of the Policy has heightened awareness and provided opportunities for various actors to articulate their views and make inputs into the new policy. The approach also promoted collective ownership of the policy by all Stakeholders.

One notable feature of this Policy is the emphasis on "INNOVATION" which has become a global tool for Fast Tracking Sustainable Development. This policy is a clear demonstration of the Country's renewed commitment to ensure that our R\&D engagements enhance new business development, encourage employment generation as well as Wealth Creation through the proliferation and growth of Small Scale Enterprise (SMEs), that are ultimately translated into good and services in the Market Place.

The efforts of all the Staff of the Ministry of Science and Technology (FMST) and her agencies particularly the National Centre for Technology Management (NACETEM) for anchoring the development of the new ST\&l policy is commended and acknowledged. Specifically, the various contributions of Members of the Academies of Science and Engineering, the Chambers of Commerce and Industry, Manufacturers Association of Nigeria (MAN), National Universities Commission (NUC), Committee of Vice Chancellors (CVC), the Military, Cognate Ministries as well as our Development Partners for their support and useful contributions to the revised policy is appreciated. Members of the National Assembly, Former Honourable Ministers of Science and Technology - especially, Prof. Mohammmed Ka'oje Abubakar, Dr. Alhassan Bako Zaku; and many Policy experts and eminent Nigerians are also appreciated for their time and invaluable inputs to the successful completion of the policy. 


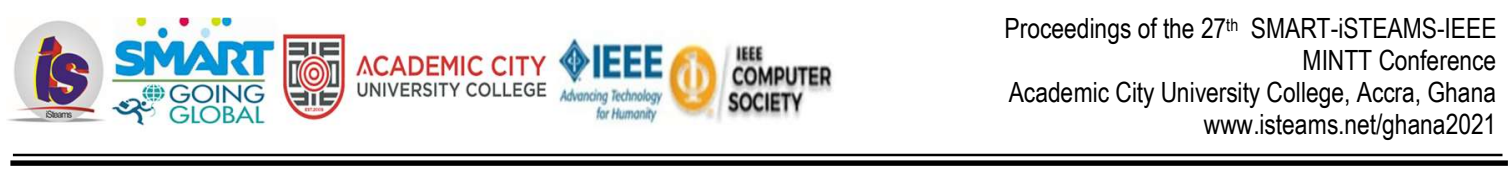

This new National Science, Technology \& Innovation (ST\&I) Policy vividly articulates workable strategies for achieving the Transformation Agenda of the former administration. All Stakeholders were called upon to strongly support the policy and actively assist in its thorough implementation. (Ita, 2012). The Federal Ministry of Science and Technology Management has undertaken to review the National Science, Technology and Innovation (ST\&I) Policy as a response to the need to carefully mainstream ST\&I into all Sectors of the economy. The Ministry has existed for over two decades and has accumulated substantial capacity in the areas of research and development, acquisition and adaptation of foreign technologies, as well as addressing the needs of the Organised Private Sector (OPS). The current effort has been guided by past policies which provided justification and inspiration for all National S\&T development programmes executed over the years. These policies were subjected to thorough review by Experts and Scholars and a new National S\&T Policy has now been approved by the Federal Executive Council.

Indeed, Nigeria has now entered into a new phase in her development strides, with inherent emerging challenges within the context of the evolving globalization. These have been conceptualized in the National Vision 20:2020 and the Transformation Agenda of Mr. President with definitive roadmaps to provide focus for ST\&I intervention in all the key Sectors of the economy. It is within this broad vision that the existing policy was reviewed. It is therefore, imperative for the Federal Ministry of Science and Technology (FMST) Management to appreciate the efforts of past leadership of the Ministry who have conceived and implemented the earlier versions of the policy with outstanding landmark achievements to showcase for the investments over the years. The contributions of Staff of the Ministry and the Agencies, especially NACETEM who have provided indefatigable support to the Management in the course of developing the current policy were appreciated.

The technical aspect of the development of the current policy benefited from a wide spectrum of Stakeholders from the Higher Education Institutions and Regulatory Bodies, Organised Private Sector (OPS) and the Public Service at both Federal and State levels. The overwhelming support enjoyed by the policy is not only an indication that the time for the Vision was ripe. It also signals the inclusiveness and accommodation of divergent views which the policy embodies. All the Stakeholders, Chairmen and Secretaries of various Expert Committees, Members of the National Assembly and all the S\&T Professional Associations were appreciated for their untiring support for the development of the policy document.

Our International Development Partners, the World Bank and the UNDP were appreciated for their Financial and Technical support towards the development of the new policy. Their support underscores the resolve of the International Community to complement the efforts of the Nigerian Government, an indication of the renewed faith in the capacity of our Government to lead the Country on the path of sustainable growth and development. The Lord God Almighty, has made this whole effort to come to fruition. The wisdom God bestowed on the leadership and synthesizing the input from the various Stakeholders is great. God guided and led us aright as we go into the implementation phase of the policy document (Jimeta, 2012).

The cardinal objective of accelerating development, competitiveness and creation of wealth for all Nigerians mark the beginning of Nigeria's intent to formulate and implement the National Vision 20:2020 Economic Transformation Blueprint (NV20:2020). Achieving the objectives of this Vision will be anchored on Three Pillars of optimizing the nation's key sources of economic growth, guaranteeing the productivity and well-being of Nigerians and fostering Sustainable Economic Development. 


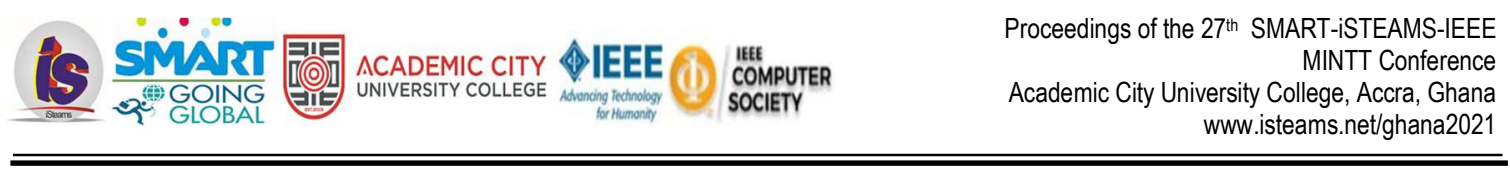

The 2012 Science, Technology and Innovation (ST\&I) Policy was designed in tandem with the Objectives and Pillars of the NV20:2020 so as to resolve practically the long standing disconnect between economic Planning, and Science and Technology. The new policy of ST\&I thus has as its core mission the evolution of a new Nigeria that harnesses, develops and utilizes ST\&I to build a large, strong, diversified, sustainable and competitive economy that guarantees a high standard of living and quality of life to its citizens. Specifically, the new ST\&I Policy is designed to provide a strong platform for Science, Technology and Innovation engagements with the Private Sector for the purpose of promoting sound economic transformation that is citizen centred.

To effectively foster a seamless engagement of ST\&I with the desired transformation, the policy has recognized also the weaknesses of the National Innovation System and thus set out to strengthen structures for the Coordination, Promotion and Management of interactions within the system. This is to reduce and eventually eliminate the current high level of "STAND ALONE" research efforts scattered all over the Country and forge Synergies among system components that will identify common problems and pool resources for research, tie research agenda to national priorities and reduce the time-to-market of research activities. In forging seamless interactions within the system of innovation, the policy will support creation of and maintenance of up-to-date, reliable and accessible database of Nigeria's ST\&I resources (Human and Material) and activities needed for Sound Economic Planning and Policy Making.

As a system that optimally allocates resources among competing needs and encourages interactions among Individuals, Businesses, Firms and Government, an economy working perfectly permeates and affects every strata of the population. The transformation of the Nigerian economy based on Science and Technology therefore is the transformation of the Nigerian people, Organisations and Institutions into Science and Technology Thinking Entities.

The new ST\&I Policy will vigorously promote activities for Science Technology and Innovation (ST\&l) communication and inculcation of ST\&I culture in Nigerians. The success of the new economic transformation blueprint will especially require the Institution of Science and Technology Thinking as a way of seeing and doing business at all strata of the Society, from the Household and Small Business levels to all tiers of Government.

It is our collective interest as a people in a Nation to therefore pursue the implementation of this policy which was designed to drive the economic Transformation Agenda and deliver its objectives as an integral part of the Nigerian Vision (NV) 20:2020 (FMST, 2012).

Nigeria's national aspiration is captured in its Vision 20:2020 multi-development plan which expressly states that "By 2020, Nigeria will be one of the 20 largest economies in the world, able to consolidate its leadership role in Africa and establish itself as a significant player in the global economic and political arena". Being that 2020 is just around the corner, it is more realistic to extend the horizon of targeted socio-economic might to match the global Sustainable Development Goals (SDG) 2030 to which many Countries currently align. Of course, Nigeria has its own peculiarities and interests that require adjustments of targets to suit its circumstances. Ultimately, the interest of any Country is to devise systems and processes for Sustaining Developments to provide affordable goods and services to its Citizens. For any Country, Sustainable Development rests on Four Pillars: The Optimization of which determines National well being; Economic Development, Population Management, Environmental Stewardship; and Social Equity. 


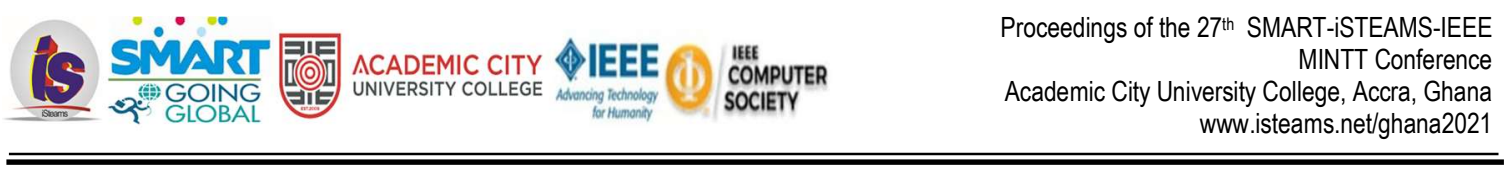

As Nigeria grapples with the challenges of Sustainable Development through Diversification of Economy, it is noteworthy that maximization of economic development without Environmental Stewardship is CounterProductive. The targeted approach in many Countries is to green the economy as much as possible. Environmental Sustainability is not the anti-thesis of Economic Progress although, it has been deduced through Review of the World Economic Database in 2006 that a 400 increase in Global Economy was achieved with $60 \%$ degradation of major ecosystem goods and services over the previous 100 years. (Inyang, 2016).

\section{HOW TECHNOLOGY CAN DIVERSIFY ECONOMY}

In the present Globalized World, Science and Technology is the bench mark on which national progress and development is measured. No nation can be competitive in the modern world without properly harnessing and developing its Science and Technology potentials. Socio-economic development is in most part dictated by the Techno Scientific advancement, a global trends that is glaring.

The strategy on how Technology can diversify the nation's economy is focused on Four (4) key elements.

(a) Re-orienting values

(b) Reducing poverty

(c) Creating wealth

(d) Generating employment in realization of national goals to improve the quality of life in Nigeria (Abdulahi, 2010).

The requirements or agents are;

a. Talents.

b. Infrastructures.

c. Material Resources

d. The Embedding of Science and Technology (S \& T) Innovation.

(e) Chemists in Nigeria corridors of power should obtain the necessary connections for political appointment so that our interest is represented when taking major decisions on Science and Technology.

(f) We should articulate a policy that will harness Science and Technology in practicable and functional ways for sustainable development.

(g) We should be more productive in terms of Patents as well as research and publications (Abdulahi, 2010).

(h) We should improve productivity in accordance with government policies by propagating the results of Scientific and Technological Research to benefit the Country in Sectors such as Agriculture, Industry, Commerce and Health.

(i) The drive towards advancement in Technology ought to move in Three interrelated Directions.

* Improvement of Indigenous Technologies to revive self confidences in our potentials.

* Understanding the Imported Technology transferred on our needs and resources.

* Development of New Technologies based on Needs and Resources and the Competitive Advantage which it offers.

(j) These Technologies should reach the market as quickly as possible. 
(k) For Higher Institutions in this Country to progress, detail attention must be paid to Infrastructural Facilities, Equipment, Laboratories, Libraries, Human Capital Development, Quality of Research and Publications.

(1) For any National Economy to Compete Internationally there is need for manpower with the right skills and productivity through the National System of Innovation (NSI).

(m) There should be an Institutional arrangement between Universities, the State and Industries aimed at generating University Spin - Off Firms, Internal Initiatives for Knowledge - based economic development and strategic alliance among Firms (Large, Medium and Small Operating Firms in different areas with different levels of Technology for the National System of Innovations to Succeed.

(n) A straight forward benefit of Science and Technology for the demand side of the economy lies in the provision of Quality Control, Standardization and Measurement Techniques, International Standards and Measurability are important since they will allow Nigeria Products to Benchmark themselves against, and conform to Global Standards (Abdulahi, 2010).

(o) We should therefore provide adequate Funding for Science and Technology Sector, ensure a stable polity and a conducive Science and Technology environment that encourage Local Researchers and lure home those abroad, while ensuring a well Coordinated National System of Innovation under the aegis of the Federal Government (Abdulahi, 2010).

\section{Challenges of Vision 20: 2020}

* Nigeria's Current Rankings in the World makes Vision 20: 2020 look bleak or totally impossible:

- $\quad$ CIA World Fact Book Ranked Nigeria as the $41^{\text {st }}$ on the list of Development Economies based on GDP for 2007.

- $\quad$ For the same year, World Bank Ranked Nigeria 40 th

- $\quad$ On the Group Description of Knowledge Index, Nigeria Ranked 66 ${ }^{\text {th }}$ amongst the Lagging Followers Group

- $\quad$ On the Global Competitiveness Ranking, Nigeria Ranked 95 ${ }^{\text {th }}$ (Adewoye, 2010).

\section{Vision 20: 2020. Is it Achievable?}

* Daunting as these challenges may seem, Vision 20: 2020 is not achievable (Adewoye, 2010).

* Our way of thinking and doing things must however be different.

* Though, it took Britain 58 years to double its Per Capital Output, China has been doing it every 7 years in the last 2 decades

* Compared with their predecessors, they did things differently.

* They invested in manufacturing; Advanced Manufacturing Technology (AMT)

* Using AMT, the Chinese have become the Fourth Growth Zone along with the United States, Japan and Germany (Adewoye, 2010). 


\section{ON THE WAY FORWARD, SCIENCE GOVERNANCE IS IMPORTANT}

* The Professional, Intellectual Apparatus and Ideological Commitment of Policy Makers and Science Administration are very crucial to the attainment of building and utilizing Science, Engineering, and Technology Innovation (SETI) capacity for National Development.

* In Nigeria's Economic Management at the top echelon, no Single Scientist of note sits on any of the Two Bodies.

* There is need for correction here in order to facilitate the required synergy to realize the nexus between Science and the National Economy.

* The prevailing National Dictum of buying \& not making which export our jobs and competencies needs to change (Adewoye, 2010).

\section{Innovation, Invention \& Intellectual Property}

* Knowledge, ideals and people who generate them - is the new currency.

* Innovative capacity will be the key driver of future economic prosperity.

* Competition is not for control of raw material, but for the most dynamic strategic asset: "productive knowledge"

\section{National Innovation System Links S \& T to Economic Growth}

* A Technological Innovation cannot be said to have been fully implemented until it has been introduced on the Market (Product Innovation).

* Innovations therefore involve a series of Scientific, Technological, Organizational, Financial, and Commercial activities.

* A key ingredient in the transformation of an innovative ideal to an innovative product is Entrepreneurship.

Fostering economic democracy and entrepreneurship is one tool for Self-Sufficiency (Adewoye, 2010).

\section{Harnessing Science \& Technology Research Results for Sustainable National Development} The Nigerian Vision 20:2020

- Be one of World's 20 Largest Economies by 2020 based on Remarkable Potentials:

* Population of 150 Million

* Median age of 18.63 years

* Proven resourceful people

* 8th Largest Oil Exporter

* 6th Largest Producer of Gas

* $\quad 34$ different Minerals

* Rich arable land and friendly climate

- Assumptions underlying the Vision:

* GDP growth from $3.5 \%$ (2009) to $7 \%$ (2015) to $13.5 \%$ (2020)

- Poverty level will reduce from $70 \%$ to $30 \%$ in 2020 (using $\$ 2 /$ day).

* Power supply increase from 3 000MW to 5 0,000MW in 2020 (Ibidapo, 2010).

- However, significant investments in S\&T education lead to innovations.

* Need for leadership 'Yes! We can attitude and work together.

* Need to strengthen STEM (Science, Technology, Engineering and Maths) education. 
* Vision 20:2020 education free at Primary and Secondary levels by 2003 and 2009 respectively, $26 \%$ or more of National Budget to Education.

* More than visions, time to implement e.g. Science, Technology and Innovation (STI).

- STI more than Traditional Sciences but includes Humanities.

- "In the final analysis, it is basically the mastery and utilization of modern S\&T that distinguishes the South from the North- Abdul Salam (I979 Nobel Laureate in (Ibidapo, 2010)).

- $\quad$ Need to develop capacity for processing Mineral/Agricultural Products

- Metrics for determining knowledge economies GDP, R \& D expenditure, Patents, electricity etc (Ibidapo, 2010).

- For example need to achieve I,000W Per Capita

- STI results Japanese Post World War II economic expansion Teknion University \& Weizmann Institute in Israel, China etc.

- Sound Scientific knowledge fundamental to addressing Micro-Economic Transformation, Bio-fuels, Embryonic Stem Cells, GM Crops etc.

- Knowledge accumulation accelerated by ICT.

- Targeted R\&D needed to fast-track developing economies.

- Reverse Engineering Research Institutes provide road-map to circumvent roadblocks to Indigenous Technology Enhancement (NASENI).

- National S\&T Strategy Consult

- Change from Consumer to Producer Nation WTO, GATT Agreements, WMO Montreal Protocols reviewed.

\section{STRATEGIES AND CHALLENGES}

* STI Vision: "To build an STI system that will drive competitive knowledge economy towards 20-2030.

* $\quad 1^{\text {st }}$ strategy build Science Based Workforce

- $\quad$ Share of manufacturing foreign and 50\%by 2020 to increase from 4\% (2009) to $20 \%$ (2015).

- $\quad$ Productivity improvement $25 \%$ by 2015 and $50 \%$ by 2020

* $\quad 2^{\text {nd }}$ strategy Forge National Innovation System encompassing existing \& new STI Institutions:

- $\quad 5 \%$ of R\&D Patentable 2015 (50,000 apps) and by 2020 (100,000 apps).

- $\quad 30 \%$ of Patentable R \& D commercialized by 2015 and $50 \%$ by 2020

- $\quad$ Expected increase in investments (Public / Private) in activities to $5.6 \%$ by 2020.

* 3rd Strategy Engender Culture of STI in Society:

- Improve emoluments of S\&T Professionals.

- $\quad$ Pre-1980 Policy of Enhanced Scholarships to Science and Technology (S\&T) Students.

* 4th Strategy for Government: Commitment through creation of National Foundation for Science, Innovation and Competitiveness.

Also National Awareness of S\&T in populace.

- $\quad$ Reinforce Strong Academic Background (Ibidapo, 2010).

\section{Other Strategies:}

- $\quad$ Emerging Technologies (Biotech, Nanotech, Project Ogodometrics International).

- $\quad$ Develop renewable energy sources.

- $\quad$ Space capabilities for Socio-Economic purpose.

- $\quad$ Promote value addition to Agro, Mineral and Petroleum Resources 
- $\quad$ Optimize use of research facilities \& Humans.

- $\quad$ Enhanced IT capability

- Development of Indigenous and Orthodox Medicine

* Challenges Against Nigerian Vision (NV) 20:2020 Include:

Lack of Political Will, Policy Inconsistency.

- $\quad$ No STI-Supporting Infrastructure

- $\quad$ Under-funding of Research ETF

- $\quad$ Activities/Scope of Research and Development (R\&D) Institutions limited

- $\quad$ Non-identification of Areas of Comparative Advantages

- $\quad$ No linkages between R\&D, and Manufacturing

- $\quad$ Inhibiting Cultural Practices and Superstition, Professor Obe summarized by stating that:

- Wealth of Nations measured by inherent knowledge

- $\quad$ Research Institutes, Universities \& Academy Key Role

- $\quad$ Research Institutions to develop Research Policy with an agenda

- $\quad$ Challenges to Nigeria Vision (NV) 20:2020 can be overcome through S\&T

- $\quad$ Build capacity for appropriate Technologies Merit-Based System

- $\quad$ Train Scientists, Engineers etc.

- $\quad$ Promote Grass-Roots inclusive Innovation

- $\quad$ Develop Technology Transfer Know How (Project Ogodometrics International for International Reference Standards for Technology Transfer) (Ogodo, 1990; Ogodo, 1996; Ogodo, 1999; Ogodo, 2000; Ogodo, 2001; Ogodo, 2005B; Ogodo, 2007; Ogodo, 2008; Ogodo, 2009; Ogodo, 2010; Ogodo, 2011B; Ogodo, 2012A; Ogodo, 2013; Ogodo, 2014; Ogodo, 2015; Ogodo, 2016; Ogodo, 2017; Ogodo, 2018; Ogodo, 2019; Ogodo, 2020).

- $\quad$ Strength Capacity of Local Science Institutions to conduct research

- $\quad$ Collation and Marketing of S\&T Research Results by Nigeria Academy of Science (NAS) (Science) and Nigeria Academy of Engineering (NAE) (Engineering) (Ibidapo, 2010).

- Open and lead Markets

- Innovate

- Take risks

- $\quad$ Entrepreneurship in the Curriculum of Science and Technology studies is crucial.

- $\quad$ This needs to be done for Science and Engineering Curriculum in the Universities Nationwide. 
Table 1: Countries That Have Heavily Invested In R\&D Have Reaped Substantial Economic Benefit

\begin{tabular}{|l|l|l|l|l|l|}
\hline & $\begin{array}{l}\text { SOUTH } \\
\text { KOREA }\end{array}$ & CHINA & INDIA & $\begin{array}{l}\text { SOUTH } \\
\text { AFRICA }\end{array}$ & NIGERIA \\
\hline $\begin{array}{l}\text { Population in Million (2007 } \\
\text { Estimate) }\end{array}$ & 48.0 & 1329.1 & 1164.7 & 49.2 & 147.7 \\
\hline $\begin{array}{l}\text { R\&D Expenditure as \% GDP } \\
(2000 \text { - 2005) }\end{array}$ & 2.6 & 1.4 & 0.8 & 0.8 & $0.20^{*}$ \\
\hline $\begin{array}{l}\text { Researchers in R\&D Per } \\
\text { Million People (1990-2005) }\end{array}$ & 3187 & 708 & 119 & 307 & $125.9^{*}$ \\
\hline $\begin{array}{l}\text { Royalties and License Fee in } \\
\text { USD Per Person (2005) }\end{array}$ & 38.2 & 0.1 & - & 0.9 & $?$ \\
\hline $\begin{array}{l}\text { Patents to Residents Per } \\
\text { Million People (2000-2005) }\end{array}$ & 1113 & 16 & 1 & - & $?$ \\
\hline
\end{tabular}

Source: Human Development Report, 2007/2008/2009.

1. Developing Nations can no longer compete based only on their natural resource endowments and location advantages.

2. For a Nation to withstand in this era of globalization there is need for such to identify its niche areas and build on it by application of Scientific Methods (e.g. Brazil: SUGARCANE; Malaysia: OIL PALM, Ethiopia: Cut Flower, Now Nigeria:

3. International Reference Standards Through Project Ogodometrics International (which Way? High-Tech? Low-Tech?).

4. What kind of $R \& D$ do we need? High - Tech? Low - Tech?

5. No economic gains from R \& D unless the outputs (including Patents) are exploited (Siyanbola, 2010).

6. Translation to innovation occurs through Entrepreneurial activities that take care of Marketing.

7. When $R \& D$ is demand driven and solves real life problems model for the relationship among Research, Development and Diffusion

a = Research and Development;

$\mathrm{b} \quad=$ Commercialization;

c = Publication, etc;

$\mathrm{d} \quad=$ Research, Development and Diffusion,

e $\quad=$ the National Innovation System (NIS), the domain in which all activities take place.

However, it is pertinent to note that Science \& Technology, as a way of life, is not a field for short-term engagement. It is a full-life engagement. Scholars whose names top the list of contributors to Science \& Technology in the World did not only start as Children, but actually devoted their lifetime to it. Examples abound in such Great Men as Isaac Newton of the Mathematics and Physics Fame; Thomas Edison the Incandescent Lamp Inventor; Lawrence Oppenheimer (Atomic Energy), Mendeleev, the Periodic Table Inventor, Michael Faraday (Electromagnetic Forces and Gregor Mendel (Genetics). Today, in the USA, Young Bill Gates is a Leading World Computer "Guru". These are but a few examples of World's Worthy Citizens who have found it worthwhile to pursue Science \& Technology, and had changed the history of the world for good. But the truth is that Nigeria is not short of people endowed with brains to do better. But do we have the Political will to encourage them? What lessons did Nigeria learn from the Biafran War? 


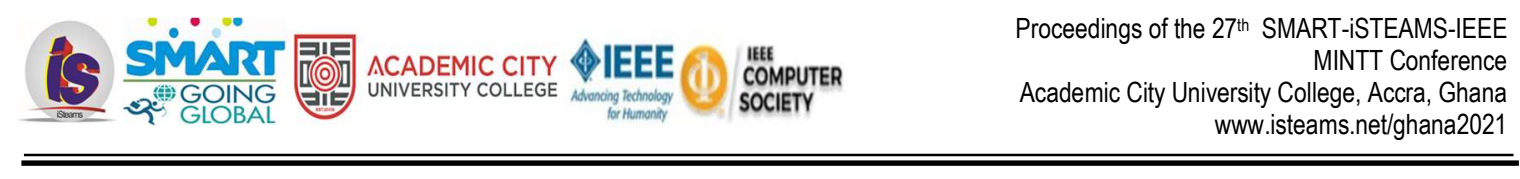

Can Nigeria emulate Japan in making Science compulsory for every Nigerian Child? These questions constitute good food for our thought menu (Egunjobi, 2003). The hope we all have for a better tomorrow and indeed for a better future depend on those Inventors and Innovators who have and are striving to make the World a better place through their creative energies and sustained hard Work (Egharevba, 2010).

Nigeria's desire to be one of the 20 Leading economies in the World by this year 2020 would be a mere dream except Science and Technology takes the Leadership Role as the Chief Driver of the Nation's Vision Agenda, if Ogodometrics is challenged in using Innovative Technology Transfer for common regulation of Intellectual Property Rights (IPR) Policy through International Reference Standards for Regulation in Nigeria through Synergy/Collaboration (Ogodo, 2009A).

Vision 20/2020 cannot succeed without Science and Technology (Onowualu, 2008). Nigeria is endowed with so many Chemists and it is painful for her not to be among the industrialized nations of the world due to our inability to generate a National Vision (such as Projects Ogodometrics International) Vision 20:2020 Target for Songhai - Delta, Amukpe Sapele Innovative Technology Transfer and implementation with distinct strategies to accomplish set goals through documentation and modalities for it implementation in research and development and create a desire in citizens to patronize indigenous efforts, and avoid the importation of items that can be manufactured within Nigeria and promulgate the Packaging Container Law (PCL) by signing a Global Memorandum of Understanding (GMOU) with other Countries/ ISO/SON and declare that without a Packaging Added Value (PAV) of Ten Naira (N10.00) (Ogodometrics) Per every bottle of Finished Product imported into Nigeria, other Countries cannot bring their finished products to Nigeria or Africa (Ogodo, 2008A). Also effective management of existing Manufacturing or Allied Companies in Nigeria with improved maintenance culture, with virtues that we lack in this Country (Nigeria) is necessary to achieve this greatness. These and other virtues are very important for our Nation Nigeria to transit to an Industrial Nation. Chemistry is truly fundamental to industrialization (Igbuku, 2009).

\section{Various Professional Bodies Communiques: Wither Our Resoution?}

In the face of the apparent indifferent attitude to the litany of communiqués after successive Professional Bodies Conferences by relevant Government Agencies (and by Chemists themselves?), one cannot but ask, "Whither our Communiqués" or even more importantly, "are they mere rituals?"... It is either the Government and/or their Agencies are not aware of the various Professional Bodies, or they (Government) view Nigeria Chemists with collective contempt, or the various Professional Bodies does not get the various Government sufficiently involved since, for instance, Governments are not expected to work with the Communiqués whose parent Conference they were neither aware or nor participated in (Ogodo, 2012 \& Alaneme 2009).

\section{WHAT YOU SHOULD KNOW ABOUT PROJECT OGODOMETRICS INTERNATIONAL}

\section{Technical Know-How}

- Registration of Technical Know How and agreement of the Transfer of Technology to Nigeria Companies involving "invisible transactions" in respect to the following:

- Use of Trademarks, Patents or Inventions.

- Supply of Technical Expertise or know-how.

- Consultancy (NOTAP NEWSLETTER, 2018B).

- Supply of basic or detailed Engineering Design.

- Provision of Operation Staff or Management assistance and the Training of Personnel. 
In registering Technology Transfer Agreements, PROJECT OGODOMETRICS INTERNATIONAL ensures that the terms and conditions in the agreement are fair and equitable to both parties and the payment involved are commensurate with the service rendered by any Foreign Partners.

- Assessment of agreements to ensure Technology Transfer (Research and Development(R\&D)) and encourage domestication, engagement of local enterprise, capacity building, and value addition to raw materials among others.

- Insurance of Certificate to Companies to enable them remit Foreign Exchange, through Central Bank of Nigeria (CBN), for the payment of Royalty/Licensing Fees.

- Monitoring the execution of registered Technology Transfer Agreements (TTAs) to different Countries to ensure effective adaptation or skills acquisition, capacity utilization, backward integration, R\&D linkages with Research Centres and Institutions of Higher Learning, Local Material utilization and equitable and fair pricing of Technology.

- Acquisition of Technology through the following activities.

Commercialization of R\&D results and invention e.g. International Reference Standards for Technology Transfer (NOTAP NEWSLETTER, (2018B).

- Establishment of Intellectual Property and Technology Transfer Offices (IPTTOs) in Research Institutions and Institution of Higher Learning.

- Technology Innovation promotion through the following Programmes:

- Provision of Patent support for Technology Buyers/Firms.

- Intellectual Property Capacity Building Programmes for Foreign Investors.

- Workshop, Seminars and Techmarts for Foreign Investors.

- Research Industries linkages through the provision of support services and the dissemination of Technology information to Foreign Partners and Industries.

Financial Saving For The National Economy From The Review of Technology Transfer Agreements.

Project Ogodometrics international's: Intervention in Technology Transfer (ITT) revenue will lead to the saving of over N200bn in Foreign Exchange Transaction involving Royalty/Licensing Fees payment between Nigeria and Foreign Partners.

\section{Proposed Projects}

- Public Private Technology Partnership (PPTP) Programmes in collaboration with Foreign Partners on promotion of Technology Innovation e.g. International Reference Standards for Technology Transfer.

- Technology Domestication Programmes.

Nigeria Development: Towards the attainment of Nigeria Vision 20:2030

\section{Visions}

- Registration of Technology Agreements (NOTAP NEWSLETTER (2018A).

- Automation/Computerization.

- Technology Service Scope Analysis.

- Industrial Sectorization.

- Development of Natural Niches.

- Technology Acquisition (NOTAP NEWSLETTER (2018A).

- Research and Development(R\&D) Capacity Mapping. 
- Research and Development (R\&D) Prioritization.

- Science Technology and Innovation(STI) Sensitization.

- Network and Partnership.

- Matured Technology Identification Patenting and Intellectual Property Rights (IPR).

- Technology Promotion.

- Commercialization (NOTAP NEWSLETTER (2018A).

- Exhibitions.

- Cluster Formations.

- Science and Technology Parks.

It is my strong belief that meeting the SDGs Nigeria Vision (NV 20:2030), implementing the National Research and Innovation Funds and Agenda and attaining Science Technology and Innovation (STI) if backed by the political will to drive the national economy (Chemistry in Nigerian Magazine (2002).

\section{WAY FORWARD}

If the Nigeria National Government through it's National Research and Innovation Funds Agenda will do anything better towards achieving the SDGs Nigeria Vision NV.20:2030 in the Country, the Government should sign a Global Memorandum of Understanding (MOU) with the United States of America President, South African Government /Isreal /South Korea Government/Harvard University America, World Innovation Council (WIC)/World Intellectual Property Organization (WIPO) and sell this Technology Transfer (Ogodometrics) to them to improve the global economic meltdown of Nigeria and the rest of the world. We do more talking than action. What we need in Nigeria is ACTION NOW AND NOT TALKING.

Nigeria has over the years initiated policies and effort to attempt to launch her technological revolution. The establishment of various Research Institutes and Specialized Technological Institution attest to this. However, the poor implementation of the various policies and shortage of the requisite funding has been the bane of the take off of her indigenous Technology Revolution in the Industrial Sector through Rebranding Nigeria (Ogodo, $\left(2011^{A}\right)$.

National breakthrough requires concerted effort and co-operation among Government and the Private Sectors. It is high time adequate measures are put in place so that the Scientific Findings and Technological development project by our experts are Commercialized as National Projects. This will greatly dampen unintentional Technology Transfer to other Countries who will Commercialized on what we discovered (Ogodo, $\left.2011^{A}\right)$.

In the words of Martin Luther:

The prosperity of a Country depends, not on the abundance of it's revenues, nor on the strength of its fortification, nor on the beauty of its public buildings, but it consists of its cultivated citizens, in its men of education, enlightenment and character (Tai Solarin, Undated). In Nigeria, the long neglect of Science and Technology including poor funding of the Research and Development are more responsible for it economic woes. 


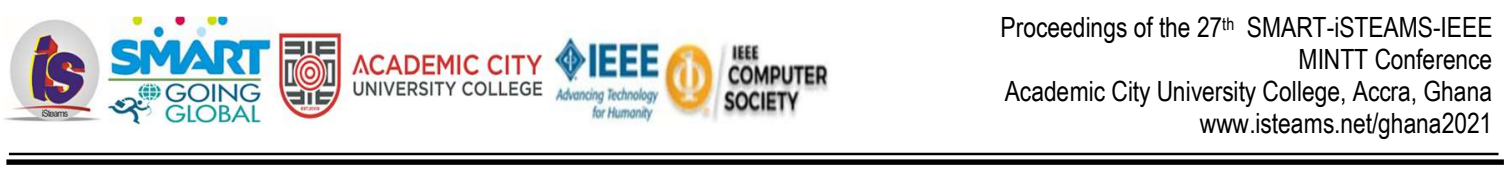

Nigeria is by all standards, an endowed nation with the vast human and natural resources. Despite this and many other features, Nigeria remains an undeveloped nation years after its independence. It fortune has been fluctuating due to several years of neglect, mismanagement, inconsistent and poorly conceived government policies. Stories have been told many times about how Malaysia got its First Oil Palm seedling from NIFOR, Nigeria in the early 1960s when Oil Palm produce was already a major export of Nigeria. By 1990, it was estimated that Malaysia's export of Palm Oil produce earned it more than Nigeria earned from Petroleum exports, and Nigeria has been a net importer of Palm produce. What a tragedy. Today, knowledge in all its forms plays a critical role in economic processes. Nations which develop and manage their knowledge assets perform better. Nigeria as a nation must rethink its place in the global economy in an age of unprecedented growth in Scientific and Technical knowledge. Nigerian's central challenge is to foster a new culture of Technological Innovation in an age of Technological opportunities. This is important because in an increasingly knowledge-based global economy, the wealth of a Nation is significantly determined by its capacity for innovation (Adebauro, 2003).

\section{HOW PROJECT OGODOMETRICS INTERNATIONAL STARTED}

\section{Global Brands - How Project Ogodometrics International Good Idea Will Become A Great Global Business}

1. OGODOMETRICS WORLD KNOWN GLOBALLY INTERNATIONAL REFERENCE STANDARDS

2. PIONEERS IN SILICA-BASED PACKAGING MATERIALS. DRIVEN TO SUCCEED, SEARCHING FOR SUCCESS

1. FOUNDER: MR. OGODO AEMURERHIMEN DICKSON (SNR) (CHARTERED CHEMIST HND, PGD, M.Sc., Ph.D (IN-VIEW), C.CHEM., MICCON, MCSN, MNISLT, MNES, MSPE INTERNATIONAL. CHIEF RESEARCH SCIENTIST

2. AGE OF FOUNDER AT START: 29 YEARS

3. BACKGROUND: TRAINED AS A LABORATORY SCIENTIST. Ph.D (IN-VIEW) STUDENT IN ENVIRONMENTAL MANAGEMENT AND TECHNOLOGY (ENVIRONMENTAL CHEMISTRY OPTION)

4. YEAR OF FOUNDATION: 1990

5. BUSINESS TYPE: WORLD KNOWN GLOBALLY HARMONIZED INTERNATIONAL REFERENCE STANDARDS MANUFACTURER

6. PROPOSED COUNTRIES TO BE TRADED WITH: OVER 192 COUNTRIES

7. PROPOSED SALES AND NET PROFIT: (15.8 TRILLION POUNDS)

8. PROPOSED INCOME: \$ 4.2 BILLIONS

9. PROPOSED TURNOVER: \$2.2 BILLIONS

- SUPREME SCIENTIFIC SUPPLIES EFFURUN NEAR WARRI, DELTA STATE NIGERIA. (2002)

- SUPREME SCIENTIFIC INTELLIGENCE INTERNATIONAL GROUP

- SUPREME SCIENTIFIC INTELLIGENCE INTERNATIONAL COMPANY SUPERIOR GROUP, (2007).

- OGODOMETRICS SUPREME SUPERIOR GROUP, (2007) (David Lester, Undated). 


\section{TAKING THE FIRST}

STEP TO INNOVATE

(CHANGE YOUR WORLD)

(Excellence in Leadership Conference, 2011)

AWARD FOR QUALITY

SUPREME SCIENTIFIC INTELLIGENCE (SSI)

INTERNATIONAL GROUP

\section{NIS ISO \\ 9002/2008 \\ CERTIFIED}

\section{WORLD KNOWN GLOBALLY HARMONIZED OFFICIALLY RECOGNIZED INTERNATIONAL REFERENCE STANDARDS GIVES MAXIMUM PROTECTION}

\section{Ogodo Aemurerhimen Dickson (Snr.) (Chartered Chemist) (C.Chem.) Chartered No. 537 of $5^{\text {th }}$ May, 2007}

Ogodo Aemurerhimen Dickson (Snr.) Centre of Excellence in Technologies of Project Ogodometrics International, School of Applied Science, Department of Science Laboratory Technology, Chemistry Laboratory, Delta State Polytechnic; P. M. B. 1030, Ogwashi-Uku, Delta State, Nigeria.

Email: dicksonogodo@yahoo.com ,Tel. No.: 08030738401

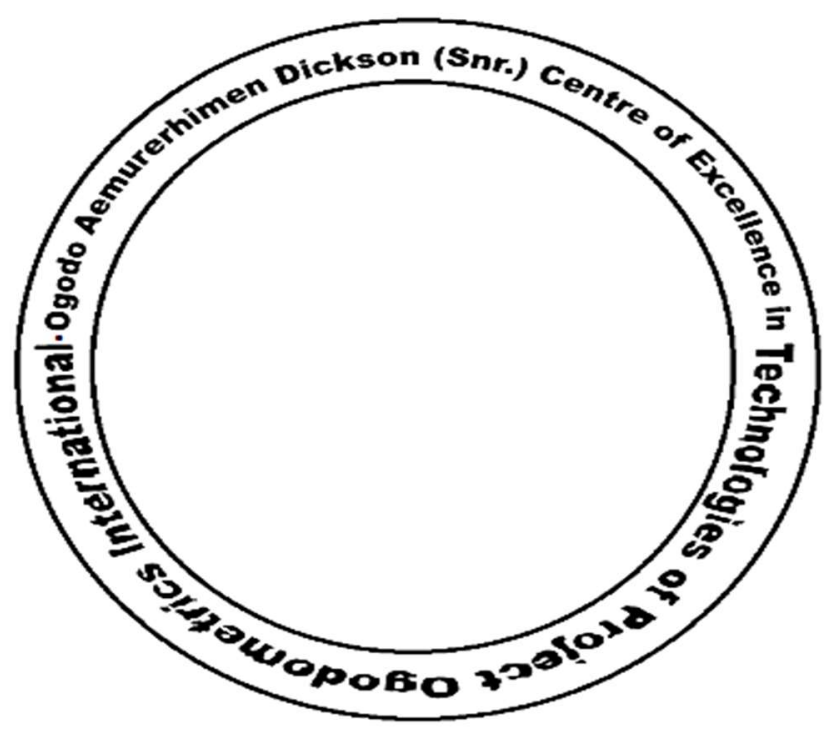




\section{STATUS OF PROJECT OGODOMETRICS INTERNATIONAL (POI)}

\section{Formulation of A Global Standard for Silica-Based Packaging Materials}

In formulating a global standard for Silica-based Packaging Materials, there will be revenue that will accrue to the Government through foreign exchange and hence Nigeria will be given a golden opportunity to supply its Technological Innovations. To this end, the Songhai-Delta, Amukpe Sapele Innovative Technology Transfer (ITT) through Project Ogodometrics International (POI) should be executed with haste in view of its economic benefits (Ogodo, 2000) through the award of sole concessionary rights for Silica-based Packaging Materials.

Project Ogodometrics will boost Nigeria's economic status and recognition in the World International Market. Project Ogodometrics International (POI) (14.0\%) will be a joint venture activity with South Africa, 15.6\%, Harvard University, USA (15.0\%) United States of America Government (25.0\%), Saudi Arabia (10.4\%). Project Ogodometrics International (POI) should be spearheaded by the Federal and State Government through Songhai-Delta, Amukpe Sapele, Delta State, Nigeria with $40 \%$ interest. South Africa, Harvard University, United States of American Government and Saudi Arabia with 20\%, 10\% and 20\% respectively. Project Ogodometrics International (POI) is the most ambitious project ever in Nigeria and is an export-based project and will be located at Amuogodo Community, Sapele, Delta State, Nigeria.

When the first train of the project eventually comes on stream, it will be able to earn foreign exchange for the government of several countries and Nigeria. The inability of the Nigeria policy formulators to foresee the great importance of global standards for Silica-based Packaging Materials is responsible for the present unfavourable situation for unemployed youths in Nigeria. Our policy makers should be cognizant of the fact that the longer we procrastinate on a comprehensive update of the New Revenue Formula for Nigeria Wealth Creation, the greater the price we have to pay in relation to non-transfer of our technological innovation worldwide.

Consequently, Project Ogodometrics International (POI) will be the best alternative to create Wealth for Nigerians and other Countries. By this project, Nigerians will benefit from Project Ogodometrics Worldwide Global Experience and Capability in technological innovations. Project Ogodometrics Global Experience and Technical Quality are a guarantee that the New Revenue Formula for Nigeria Wealth Creation using Chemistry for National Developmental Needs (Ogodo, 2011B) will contribute to Nigeria's Economic Growth, far into the future. Investment constitutes a major highlight in the diversification of the Nigeria's Economy while making significant growth in the Nation's Export of Technological Innovation and overall income (Ogodo, 2000).

Project Ogodometrics International (POI) is therefore very much on track to deliver on target and the costs of the project are within budget. Project Ogodometrics International (POI) can enter into Long Term Technology Transfer Agreement with the 4 joint ventures operated by the Federal Government affiliates of South Africa, Harvard University, U.S.A, United States of American Government and Saudi Arabia which will respectively supply $33 \%, 20.3 \%, 23.3 \%$ of the approved estimated budget for the technology transfer. These are 23 years take or Pay Contract with Project Ogodometrics International (POI) predominantly indexed to technology Transfer Price. This study concluded that there is a good market for Nigeria both with the existing countries and with other potential joint venture partners. The total time for development decision to contract award Final Investment Decision (FID) should be within one year. 


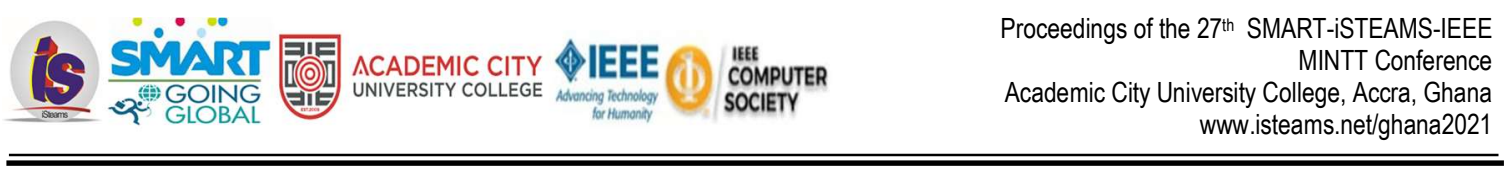

\section{Project Cost and Financing}

Project Ogodometrics International (POI) for the New Revenue Formula for Nigeria Wealth Creation using Chemistry for National Developmental Needs is a major capital project. Overall project cost including the cost of implementation will be about $\$ 2$ billion. The Joint Venture Project, which cost is around $\$ 3.6$ billion, should be fully financed by the proposed Joint Venture Partners prior to the Final Investment Decision (FID) for the project. An escrow scheme should be put in place for the funds required, provided by the proposed Joint Venture Partners who can now invest additional funds later or by Third Party Finance.

Nigerianisation And Local Content: A Nigerianisation Policy should be agreed between the Joint Venture Partners or by its Third Party Finance. It states that its ultimate objective is to Nigeianize Project Ogodometrics International (POI) workforce without compromising quality. Effective participation of Nigerians in all phases and in all aspects of the Technological Innovation is therefore a top priority of the Federal and State Governments. The experience and expertise acquired by Nigerians will enable them to play a greater role in this technology transfer. A detailed Local Content Plan should be developed to ensure maximum utilization of Nigerian Manpower and resources (Ogodo, 2000).

\section{Governance \\ Rationale}

To enhance effective Coordination, Direction and Management of ST\&I activities in Nigeria, it is essential to establish and strengthen relevant institutions and structures needed to provide sound ST\&I administration, good governance as well as quality leadership at all levels of government. To demonstrate leadership at the highest level, top priority should be given to the creation of a platform for inclusiveness, ownership, sustainability and inter-agency collaboration among key actors and stakeholders.

\section{Objective}

To create an appropriate Organizational environment of complementary relationships and network that minimizes frictions and institutional lapses for the co-ordination, management, promotion and application of ST\&I in the production of goods and delivery of services for socio-economic development.

\section{Strategies}

i. $\quad$ Creating a Governance structure that is inclusive and broad based.

ii. $\quad$ Repositioning Boards and Committees to reflect the current Policy intent and directions.

iii. Creating specific roles to avoid role duplication and confusion.

iv. Establishing an appropriate legal framework for effective Organizational management and control.

v. Strengthening the States' Ministries of Science and Technology (S\&T) and Federal Ministry of Science and Technology (FMST) as the co-ordinating institutions for all Science Technology and Innovations (ST\&I) activities in the Country.

vi. Establishing an appropriate Departments or structures in the Federal Ministry of Science and Technology (FMST) and States' Ministries/Agencies, Research Institutions and Industries.

vii. Strengthening Research and Development Institutions to enable them deliver on the policy objectives.

viii. Encouraging all Science and Technology (S\&T) Institutions, the Public and Private Sectors in the Country to carry out programmes and activities that are in consonance with the National Science Technology and Innovation (ST\&I) Policy.

ix. Carrying out mandatory periodic evaluation and monitoring of the performance of the National Innovation System. 
X. Ensuring the establishment of appropriate Science Technology and Innovation (ST\&I) monitoring of the performance of the National Innovation System.

xi. Ensuring the establishment of appropriate Science Technology and Innovation (ST\&l) Ministries/Policy Organs at the States and Local Government Levels.

xii. Establishing other relevant Science Technology and Innovation (ST\&I) Research Institutions to FastTrack Sustainable Developments.

xiii. Establish a National Research and Innovation Foundation (Backed by Legislation) to manage competitive grants for Sustainable Short and Long Term Research.

xiv. Establish a Monitoring and Evaluation System for the Policy to be managed by Federal Ministry of Science and Technology (FMST) (FMST, 2012).

\section{Governance System}

\section{Rationale}

To provide strong leadership, effective co-ordination and adequate resources for all Science Technology and Innovation (ST\&I) activities within the National Innovation System.

\section{Objective}

The position of Science Technology and Innovation (ST\&I) as National top priority endeavour to guarantee sustainable, high standard of living and quality of life for its citizenry and fast track industrial and economic development.

\section{National Research and Innovation Council (NRIC)}

The National Research and Innovation Council (NRIC) shall perform the under-listed functions:

i. $\quad$ Set National priorities on Research and Development (R\&D).

ii. Set directions to co-ordinate Science Technology and Innovation (ST\&I) activities (including Research and Development (R\&D)) in line with National Priorities.

iii. Establish new Research Institutes and strengthen existing ones as it may deem necessary.

iv. Facilitate fund raising activities to support Innovation Activities in areas of National Needs and Priorities. (Federal Ministry of Science and Technology, FMST, 2012).

\section{Governance of National Research and Innovation Council (NRIC)}

i. $\quad$ The Chairman will be the President of the Federal Republic of Nigeria.

ii. $\quad$ The Council shall consist of the following as Members:

- Honourable Ministers of following Federal Ministries:

- Ministry of Science and Technology

- Ministry of Information

- Ministry of Communication Technology

- Ministry of Agriculture and Rural Development

- Ministry of Education

- Ministry of Health

- Ministry of Power

- Ministry of Energy

- Ministry of Works

- Ministry of Finance

- Ministry of Lands, Housing and Urban Development 
- Ministry of Petroleum Resources

- Ministry of Environment

- Ministry of Water Resources

- Two (2) Representatives of the Organized Private Sector (OPS). Federal Ministry of Science and Technology (FMST) will serve as the Secretariat. (FMST, 2012)

\section{State Science, Technology and Innovation Council (SST\&IC)}

Functions

i. Provide Leadership and Directions for Science Technology and Innovation (ST\&I) activities at the State level.

ii. Promote Science Curriculum and disseminate Science, Technology and Innovation information.

iii. Align policies and programmes with those of the National Research and Innovation Council (NRIC).

v. Promote and implement decisions and programmes of the National Council on Science, Technology and Innovation (NCST\&I).

\section{Governance}

i. The Chairman will be the Executive Governor of the State while the States' Ministry of Science and Technology or its equivalent will serve as the Secretariat.

ii. $\quad$ The Council shall consist of the following as Members:

- Honourable Commissioners of Science and Technology (S\&T) and S\&T related Ministries.

- Honourable Commissioner of Finance.

- Two (2) Representatives of Members of the State House of Assembly.

- Two (2) Representatives of State Chapter of Organised Private Sectors and relevant Professional Bodies.

- Two (2) Representatives of Chairmen of Local Governments in the State.

\section{National Council on Science, Technology and Innovation (NCST\&I)}

\section{Functions}

i. Set broad directions to co-ordinate Science Technology and Innovation (ST\&I) activities (including Research and Development (R\&D)) in line with National Priorities.

ii. Collate and disseminate annual reports of achievements from all public Science, Technology and Innovation (ST\&I) agencies.

iii. Facilitate active interaction/brokerage among Government, Industry and National Research System.

\section{Governance}

i. The Chairman will be the Honourable Minister, Federal Ministry of Science and Technology (FMST).

ii. The Council shall consist of the following as Members:

1. State Commissioners of Science and Technology (SCS\&T) or its equivalent

2. Federal Cognate Ministries, Departments and Agencies

3. Academies of Science and Engineering

4. Nigerian National Merit Awardees in Science, Engineering and Technology (SET)

5. The Armed and other Security Forces

6. Organised Private Sector

7. Development Partners

iii. FMST will serve as the Secretariat. (FMST, 2012). 


\section{THE CANCER OF CORRUPTION}

\section{Our Children are Coming!}

The first thing is to dismantle and replace the entire political structure on which the Country stands. As Comrade Yekini Falase, President of National Association of Students (NAS), observed in an interview with EBC Focus on African in London, "we are convinced that no attempts to purge our Country of corruption will succeed until and unless we attack and revolutionize the entire political framework upon which everything rests. Corruption is deeply ingrained into our present political system that it is impossible to eradicate it while that framework remains intact" (lke, 2013).

According to Comrade Falase, National Association of Students (NAS) sees Political Parties as "the bedrock of corruption and immorality in our Country". He argued that a man required by his Political Party to pay \$50,000.00 deposit to vie for nomination to an elective Office could not be expected to champion the eradication of corruption if he wins the election. That was in 1990 when the novel was published. For the $16^{\text {th }}$ November, 2013 gubernatorial election in Anambra State, a major Political Party required intending candidates to pay One Million Naira for nomination. How many people with honest intentions and expectations will have the urge and the capacity to pay such a colossal amount to seek nomination for an elective Political Office? If the honest intention of a Political Party is to field persons willing and unable to offer honest service, why should a candidate be required to pay an eligibility fee of Eleven Million Naira?

One major antidote presented against corruption is the abolition of Political Parties and general elections.".... we in the National Association of Students (NAS) are convinced that Political Parties are among the trappings of Western Civilization which we have imported into our Society at our peril. They have turned out to be no more than umbrellas legitimized by the constitution to provide cover for groupings of gluttonous people to embezzle.....". Their total abolition will reduce the cost of Government Machinery by some $50 \%$, releasing the funds saved for more meaningful Development Projects (Ike, 2013).

On whether or not a Community could exist without Political Parties, Comrade Falase told the EBC interviewer that Nigerian Communities had no Political Parties prior to British intervention in Nigeria. To be eliminated along with Political Parties is the general election, which every child knows to be manifestly marred by corruption and other immoral acts (lke, 2013).

In the new system envisaged by National Association of Students (NAS), the principle of rotation will be entrenched. Every State will have its turn to provide a President for the Country. For a specified term, it will be the business of that State, and that State alone, to choose a candidate and we believe a State can do so peacefully, without undue acrimony and without Millions of Naira changing hands if Political Parties have no hand in it" (lke, 2013).

At Federal level, the position of President, Vice President, and other elective positions would rotate among States in alphabetical order. It would be the responsibility of the concerned State alone to select the next President. At State level, the State Governor and other designated responsibilities would rotate among Local Government Areas in alphabetical order. The selection of each legislator at whatever level would be vested in his constituency. Within the constituency, all positions will rotate among the towns in the Local Government Areas (LGAs), arranged alphabetically. (Ike, 2013). 


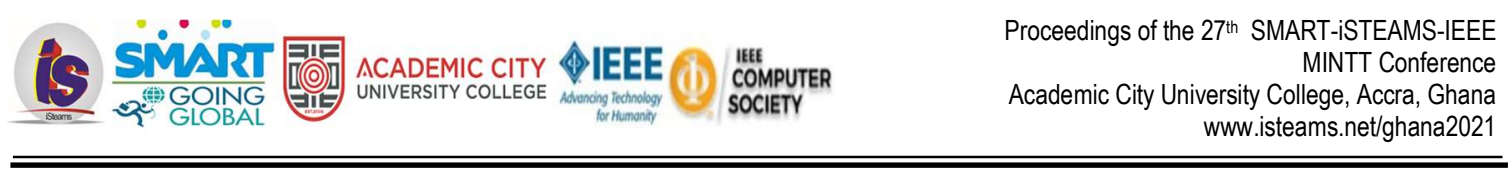

It is significant that Ike floated the principle of rotation of power among the States of the Federal Republic, as far back as 1990 when Our Children are Coming! was published and credited it to the transformational ideas by young adults - the fictional National Association of Students (NAS). In a Country comprising many States, ethnic and other divisions, the principle of rotation recommends itself as one strategy for grappling with fears of marginalization. As will be seen presently, he used his $9^{\text {th }}$ novel published a year later (The Search) to explore the principle of rotation further. Fortunately, many Political Parties years later seem to have accepted rotation generally. However, selfish considerations have stalled meaningful application of the principle to Federal, State and Local Government elections. (Ike, 2013).

Exposure of corrupt political and other Public Officers was proposed (again through National Association of Students (NAS)) as a most effective strategy for sanitizing and transforming the Nation. "We have commissioned a dossier on every leading Citizen of this Country......from Elders to Youth and not the other way round". National Association of Students (NAS) threatened to release a pamphlet "to expose some leading members of Adult in the society in their nakedness, thereby providing the public with a close-up of the Men and Women ruining rather than running the Country". Details included in the pamphlet included an account of the scandalous attempt by the Chairman of the Tribunal on the Youth to rape his female interpreter during their visit to Manila, Philippines. The shameful act, widely publicized in Manila and communicated to the Nigerian Government, was completely hidden from the Nigerian media. The National Association of Students (NAS) pamphlet also released some of the exposures in the Tribunal on Parents above 21 Years. (Ike, 2013).

The impact of the pamphlet on the Nation's Leaders exceeded that of any earthquake, forcing the President to accede to two of the three demands in the National Association of Students (NAS) ultimatum. It listed names of individuals with skeletons in their Cupboards, including Persons with Fabulous Bank Accounts, Owners of Real Estate Holdings, Ownership of Private Aero-Planes, Helicopters, Yachts and Expensive Cars, giving full particulars of their holdings within and outside the Country, at the beginning of the current administration and three years later. (Ike, 2013).As Dr. Bankole, one of the two characters, he gave the assignment of reviewing developments in the novel, observed on the impact of the pamphlet, "At long last a healthy, fundamental change was in the offing, achieved by the Young without firing a bullet. A change that would curb corruption and usher in political stability" (lke, 2013).

\section{CONCLUSION}

1 The research concludes that Science and Technology can diversify the Nation Economy through one strategy of Emerging Technologies "Project Ogodometrics International (POI) WSSD +22 in SonghaiDelta, Amukpe-Sapele, Delta State, Nigeria.

2 Chemistry and Standardization are central to all Sciences, life itself and for any meaningful development and progress to be made in life. From the foregoing, it is obvious that the National Government of Nigeria through the National Research and Innovation Funds Agenda will be sufficient in its effort to realizing the goals of the Nigeria Vision 20:2030. One of the major undoings of the present Government is its sluggishness in proactive decision taking and implementation. Given 2030, the date set aside for the attainment of the Nigeria Vision NV.20:2030, Nigeria has not realized much so far. The tendency is that if the nation does not rise on time to work extensively, the Sustainable Development Goals (SDGs) date of 2030 will run out of the nation's hands (Ogodo, 2011'B). 
3 I hope that the issues I have invoked above will form one of the basis of our discussion during this the writing of our Communique in order to finding solutions to them. The importance of research in Tertiary Institutions cannot be over emphasized. All we need to do is to look at the various gadgets that are for our present day comfort, the fit in Medical Science which has added to man's longevity, The Internet that has brought to our doorstep the vast libraries of the world at just a click; the list could be endless. They were all the products of research works embarked upon by people, most of whom were given the right landscape to perform. If Delta State Higher Education will fully make good its aspiration to reposition the status of Higher Education in the State, a worthy attention on research should be accorded its rightful place. However, with your continuing •support, I am confident that we can, together, lay the solid foundation of a bright and prosperous future for our nation. We must have the courage to do all that is right, decent and compassionate; all that needs to be done for our nation's restoration. We must do this always with strict adherence to the rule of law and due process, however inconvenient sometimes.l

4 This policy reflects the renewed commitment and aspirations of the government and people of Nigeria to deploy Science and Technology (S\&T) as the fulcrum of all activities geared towards realizing the Nation's potentials as a regional power in Africa, emerging as a global economic power within a short time. The policy seeks to build a Nation that is able to provide steadily and on a progressive basis, high standard of living and quality of life for its citizens by harnessing Science Technology and Innovation outputs as well as the energies and talents of its highly resourceful people.

The policy is thus formulated to enable Science Technology and Innovation (ST\&I) maximally impact on the National Economic Development Landscape with a view to ensuring that Nigeria emerges and remains among the Top 20 economies in the World by the Year 2030 and beyond. This policy therefore shall be faithfully implemented as an integral part of the Vision 20:2030 and the Economic Transformation Blueprint of Mr. President (FMST, 2012).

Nigeria's National aspiration is captured in its Vision 20:2030 Multi-development Plan which expressly states that "By 2020, Nigeria will one of the 20 largest economies in the World, able to consolidate its leadership role in Africa and establish itself as a significant player in the Global Economic and Political arena". Being that 2020 is just around the corner, it is more realistic to extend the horizon of targeted socio-economic might to match the global Sustainable Development Goals (SDG) 2030 to which many Countries currently align. Of course, Nigeria has its own peculiarities and interests that require adjustments of targets to suit its circumstances. Ultimately, the interest of any Country is to devise systems and processes for sustaining developments to provide affordable goods and services to its citizens. For any Country, Sustainable Development rests on Four Pillars, the Optimization of which determines National well being; Economic Development, Population Management, Environmental Stewardship; and Social Equity (Inyang, 2016). 


\section{RECOMMENDATIONS}

The research recommends that a

1. A Scientific/Technical Adviser under the Presidency is the only option for Nigeria using Science Governance of Project Ogodometrics International (POI) WSSD +22 in Songhai-Delta, Amukpe-Sapele, Delta State, Nigeria in order to facilitate the required synergy to realize the nexus between Science and the National Economy to bring 154 International Standards Organization (ISO) Countries to Songhai-Delta, Amukpe-Sapele, Delta State, Nigeria to sign a MOU with the Nigerian Government via Final Investment Decision (FID) of Technology Transfer Agreement (TTA) of Ogodo Intellectual Property Rights (OIPR).

2. Standardization of Mr. Ogodo A. Dickson Certificated Firms (Songhai -Delta, Amukpe-Sapele) for Award Winning Technology can be used as a tool for enhancing trade through Technology Transfer across the boarders of two entities in the process of economic development of both Developed and Developing Countries. The OGODO INTERNATIONAL REFERENCE STANDARDS for Silica-based Packaging Materials should be Documented, Recommended, Accepted and Implemented around the World and approved by the International Organization for Standardization (ISO) in Geneva in collaboration with Standard Organization of Nigeria (SON), National Agency for Food, Drug, Administration and Control (NAFDAC) etc after the Global Memorandum of Understanding (GMOU) is entered into between the Federal Ministry of Science and Technology (FMST), Ministry of Industries, SON, NAFDAC, HAVARD UNIVERSITY U.S.A., AMERICAN OIL CHEMISTS SOCIETY, (AOCS) U.S.A., WORLD TRADE CENTRE, WORLD BANK ETC. AND OGODO REFERENCE STANDARDS INTERNATIONAL.

3) The Songhai-Delta (Amukpe-Sapele) Innovative Technology Transfer for Silica-based Packaging Materials will be transferred to the 253 Countries of the World, the Seven Continents of Africa, North America, South America, Asia, Antartica, Europe, Australia and should be backed with the signing of a Global Memorandum of Understanding (GMOU) for Sole Concession/Worldwide Patents/Franchise Rights in Members Countries for Product Specifications and applications with qualified Professional Chemists / Scientists to attract Global Participation of Stakeholders in Industries, Academia, Scientists bringing together the Industries Professionals, Researchers, Investors, Government and Corporate Establishments to examine and Share ideas in ways to improve the Songhai-Delta (Amukpe, Sapele) Technology Transfer to Develop Local Expertise and Optimize integration of Industries with other vital Sectors of the Economies of the World.

4. This Vision 20-2030 Document should be gazetted in the Corporate Affairs Commission in Abuja.

5. A bill for a law to make provisions for the Control, Regulation and Implementation of Superior Pigmented Silica-based Packaging Materials should be enacted by the National Assembly of the Federal Republic of Nigeria and by Authority of same through the Member Representing Sapele Constituency in the Delta State House of Assembly, Hon. (Chief) Felix Anirah/Hon. Speaker of the Delta State House of Assembly, Hon. (Chief) Sheriff Oborevwori and current Commissioner for Science and Technology, Delta State, Hon. Matthew Itsekiri to recommend this acceptable Nigerian Officially Internationally Recognized Standard that will be documented as the best quality Superior Pigmented Silica-based Packaging Materials. 
6. There should be no Patent Rights/Franchise Rights/Sole Concession Rights in Proposed Members Countries such as Austria, Belgium, Denmark, Finland, France, German, Greece, Spain, Sweden, Switzerland and the United Kingdom etc without OGODO STANDARDS (NIGERIA) INTERNATIONAL (OSI) PERMISSION EXCEPT AS PERMITTED BY LAW.

7. The bill for the Implementation of this Innovative Technology Transfer should be passed into Law by the approval of the State and National Assembly in its First and Second hearing after the President, His Excellency Mohamadu Buhari has gone through it for approval to the House for Implementation.

8. A panel for the implementation of this Innovative Technology Transfer should be constituted and to submit their report while a Blue Print for the establishment and reactivation of existing Companies in Sapele, Delta State, Nigeria will be submitted to the Federal Government for Consideration.

9. Worldwide Patent Rights through domains in Professionalism can be got from America through the Assistance of Delta State Governor, Senator Dr. Arthur Ifeanyi Okowa.

\section{REFERENCES}

Abdullahi, L. G. (2010), How Technology Can Diversify Economy: Is Nigeria Ready? African Science and Technology Digest. 9 (7\& 8) July/August. Pages 29 - 32.

Adebuaro, H.O. (2003), An Address Delivered by the Ekiti State Special Adviser on Women Affairs on the Occasion of the Plenary Session-Conference on: Sustaining Children Interest in Science and Technology For National Breakthrough. $4^{\text {th }}-6^{\text {th }}$ November. Lecture Theature 322(Adetutu Hall), University of Ado-Ekiti, Ekiti State, Nigeria. $2^{\text {nd }}$ International Conference of Children-in-Science and Technology(CIST).

Adewoye, 0.0. (2010), Repositioning Science, Technology and Innovation System To Meet the Challenges of Vision 20:2020: African Science Technology Digest. July/August. P.7-8.

Chemistry in Nigeria Magazine (2002), Chemical Society of Nigeria (CSN). Communique: Whither Our Resolutions? A National Magazine of the Chemical Society of Nigeria. 2(1) September. Page 1.

David Lester (Undated), How They Started. Global Brands. How 21 Good Ideas Became Great Businesses, Edited. Beulahland Publications. E-mail: beulahland27@yahoo.com. $+234(0) 8037278994$, Member CBAN. A Catalogue Record for This Book is available from the British Library. ISBN 978185458 4472. Printed and Bound by MPG Books Ltd, Bodmin. 211 Pages.

Egharevba, F.I. (2010), Chemistry and the Quest for Discovery and Innovation. 35th Inaugural Lecture Series, Ambrose Alli University, Ekpoma, Edo State, Nigeria. 27 th May,. 51 Pages.

Egunjobi, O.A. (2003), In Times Like This, Is Science and Technology A Worthwhile Pursuit for Nigeria Children. Lead Paper Presented at the Second Plenary Session of the Second International Conference on Children-in-Science and Technology Held at the University of Ado-Ekiti, Ekiti State, Nigeria on $4^{\text {th }}-6^{\text {th }}$ November by the Deputy Vice-Chancellor, University of Ado Ekiti, Ekiti State, Nigeria.

Excellence in Leadership Conference (2011), Innovate ......... Change Your World. $9^{\text {th }}-11^{\text {th }}$ November, Daystar Christian Centre, Plot A3C, Ikosi Road, Beside GT Bank, Oregun, Ikeja Lagos. Tel: +23417937415, 8161435, 8746326. Hotline: +234803438822. Enquires: Contact us @ excellenceleaders.org. www.excelentleader.org. 
Ewa, I. O. B. (2012), Forward Written by Honourable Minister of Science and Technology on the National Science, Technology and Innovation (ST\&I) Policy. Federal Ministry of Science and Technology. 2012 Edition Reprinted 2016.

Federal Ministry of Science and Technology. (2012 Edition Reprinted 2016), National Science, Technology and Innovation Policy.

Ibidapo, 0. (2010), Harnessing Science and Technology Research Results for Sustainable National Development African Science Technology Digest. 9 (7 and 8). July/August. P.6.

Igbuku, A.O. (1999), Chemistry and Nigeria's Industrialization. The Delta Chemist (A Bi-Annual Magazine of the Delta State Chapter of the Chemical Society of Nigeria. Vol. 1 (1) October.

Ike, C (2013), The Story Teller and National Transformation: A National Merit Award Winners Lectures, 2013, Nigerian National Order of Merit (NNOM). Presented by HIS MAJESTY, EZE PROFESSOR Chukwuemeka Ike, NNOM, OFR. Under the Auspices of the Nigerian National Merit Award, House 22, J.T. Aguiyi Ironsi Street, Maitama, Abuja, on $4^{\text {th }}$ December, 2013. Published on Behalf of the Governing Board of the Nigerian National Merit Award. The Presidency, Abuja, Nigeria. 103 Pages

Inyang, H. (2016), Configuration of Policy and Technical Systems for Improvement of Nigeria's Environmental Sustainability. A National Merit Award Winners Lectures, 2016, Presented by Chair, Global United University System (GUUS) Initiative and Former Duke Energy Distinguished Professor and Director, Global Institute of Energy and Environmental System (GIEES), University of North Carolina, Charlotte, North Carolina, USA Under the Auspices of the Nigerian National Merit Award, House 22, J. T. Aguiyi Ironsi Street, Maitama, Abuja, FCT, Nigeria. Wednesday, November 30th 2016. Time 3.00pm to $5.00 \mathrm{pm}$ at Merit House (Near National University Commission (NUC), Maitama, Abuja, FCT. 59 Pages.

Jimeta, R. S. (2012), Acknowledgement Written by the Permanent Secretary of the Federal Ministry of Science and Technology on the National Science, Technology and Innovation (ST\&I) Policy. Federal Ministry of Science and Technology. 2012 Edition Reprinted in 2016.

Jonathan, G. E. GCFR (2012), Presidential Statement on the New National Policy on Science, Technology and Innovation. Published by Federal Ministry of Science and Technology, Phase 11, Block "D", Federal Secretariat Complex, Abuja, Reprinted 2016 by Luckozim Publisher Limited, Block C2, Suite 18, Commerce Plaza, Area 1, Garki Abuja.

L'ois Alaneme(2009), Technology and Intellectual Property: Critical Tools for African Development. Science and Technology Digest: (9 and 10)September/October. Pages 25-26.

NOTAP NEWSLETTER (2018B), A Publication of the National Office For Technology Acquisition and Promotion(NOTAP) on: NOTAP Publishes Guidelines' on Commercialization of Research and Development (R\&D) Results and Inventions in Nigeria. Vol.5 No. 5,Delta State University, Abraka Gets Intellectual Property and Technology Transfer Offices (IPTTOs) October-December 2018. Abuja Office: No. 4 Blantyre Street, Wuse II, Off Adeotokunbo Ademola Crescent, Wuse II, Abuja. Lagos Zonal Office Address: No. 19 Kingsway Road Ikoyi, Lagos. Telephone: 09034776654. Email: info@notap.gov.ng.www.notap.gov.ng 19 Pages.

NOTAP NEWSLETTER $\left(2018^{\mathrm{A}}\right)$, A Publication of the National Office For Technology Acquisition and Promotion(NOTAP) on: NOTAP Empowers Nigeraian Defence Academy(NDA) with the Establishment of Intellectual Intellectual Property and Technology Transfer Offices(IPPTOs). Vol.5 No. 3. January-March 2018. Abuja Office: No. 4 Blantyre Street, Wuse II, Off Adeotokunbo Ademola Crescent, Wuse II, Abuja. Lagos Zonal Office Address: No. 19 Kingsway Road Ikoyi, Lagos. Telephone: 09034776654. Email: info@notap.gov.ng.www.notap.gov.ng 19 Pages. 
Ogodo, A.D. (2018), Repositioning the Nigerian Economy Using Chemistry Education to Unlock the Wealth of All Nations in Songhai Delta, Ovwore Community, Amukpe-Sapele, Delta State, Nigeria. Conference on Repositioning the Nigerian Polytechnics to Meet Current Economic Needs. Event Centre, Delta State Polytechnic, Ogwashi-Uku. $1^{\text {st }}$ National Conference on Nigerian Polytechnics and National Development and Art and Engineering Craft Exhibition. 53 Pages

Ogodo, A.D. (2016), OGODOMETRICS: International Standards Organisations (ISO), Approval/Certifications/Product Design, Innovation Using Globally Harmonized International Reference Standards in Songhai Delta, Amukpe-Sapele as Targeted World Collaborative Centre. Chemical Society of Nigeria 39th Annual International Conference Book of Proceedings, 39:134-160.

Ogodo, A.D. $\left(2012^{\mathrm{A}}\right)$, The Role of Chemistry in National Transformation Through Intellectual Property Rights (IPR) for Technology Transfer - Is Nigeria Ready? A Scientific Research Paper Presented at the 2012 Chemtech Conference of the Chemical Society of Nigeria (CSN), Edo State Chapter in Collaboration With University of Benin, Benin City and South-South Zone of the Chemical Society of Nigeria (CSN) on the Theme "The Role of Chemistry in National Transformation. 500 Lecture Theatre, University of Benin, Ugbowo-Lagos Road, P.M.B. 1154, Benin City, Edo State, Nigeria. Thursday, $26^{\text {th }}$ July. 32 Pages.

Ogodo, A.D. (2011B), OGODOMETRICS: The New Revenue Formula for Nigeria's Wealth Creation Through Global Collaboration and Partnership Using Chemistry for National Development Needs. $19^{\text {th }}-23^{\text {rd }}$ September, 2011. Conference on: Chemistry and The Millennium Development Goals. Main Auditorium, University of Ilorin, Ilorin, Kwara State, Nigeria. 34th Annual International Conference, Workshop and Exhibition (Kwara 2011) of the Chemical Society of Nigeria (CSN)

Ogodo, A.D. $\left(2011^{\mathrm{A}}\right)$, Rebranding Nigeria Via Technology In Industrial Sector. $7^{\text {th }}-11^{\text {th }}$ February. Teslim Balogun Stadium, Surulere, Lagos, Lagos State, NIGERIA. Guest Speaker on the Occasion of the $2^{\text {nd }}$ National/International Association of Science and Technology Students (NASTES).

Ogodo, A.D. (2009A), Repositioning the Nigerian Economy Through Standardization and Technology Innovations. Conference on Repositioning the Nigerian Economy Through Scientific and Technological Innovation. $26^{\text {th }}-30^{\text {th }}$ October. New Multi-Purpose Hall, The Federal Polytechnic, Ilaro, Ogun State.

Ogodo, A.D. (2008A), The Study of Chemistry: A Broad Spectrum of Career for Chemists for the Service of Man while "Thinking With You". Conference on: General Studies: Goal To A Balanced Education $11^{\text {th }}$ - 14 ${ }^{\text {th }}$ March, 2008. School of Engineering Main Hall, Delta State Polytechnic, Ozoro, Delta State, Nigeria. $1^{\text {st }}$ Annual National Conference, School of General Studies. (SOGSANCON 2008).

Ogodo, A.D. (2007), Chemistry, Industry and OGODO REFERENCE STANDARDS For Silica Based Packaging Materials: The Challenges of International Reference Standards and Technology Transfer for Economic Empowerment. Conference on: Chemistry: A Key Driver for National Development and Growth. 28 $8^{\text {th }}-28^{\text {th }}$ September. Merit House/Raw Materials Research and Development Council (RMRDC), Maitama District, Federal Capital Territory; Abuja, Nigeria. Proceedings of $30^{\text {th }}$ Annual International Conference of the Chemical Society of Nigeria (CSN) Pages $144-168$.

Ogodo, A.D. (2005 $)$, Standardization of Silica-Based Packaging Materials for Regulation in Nigeria Using International Standards Organisation (ISO) 9001:2000 Standards in Songhai - Delta (AmukpeSapele) Innovative Technology Transfer and Implementation Project. A Paper Presented During the $21^{\text {st }}$ Annual National Conference of the Nigerian Institute of Science Laboratory Technology (NISLT) Held at Shehu Musa Yar-Adua Centre, Abuja October. 49 Pp. 
Ogodo, A. D. (2000), Assessment of the Significance of Liquefied Natural Gas to the Nigerian Economy. PostGraduate Diploma (P.G.D) Thesis, Ambrose Alli University Ekpoma, Edo State, Nigeria, December, Pages 48-59.

Onowualu, P. (2008) Can Vision 2020 Succeed Without Science and Technology? Science and Technology Digest. 7 (4 \& 5) April/May. P. 15 - 18.

Siyanbola, W.O. (2010), On Research and Development and the Challenges of Wealth Creation in Nigeria. African Science Technology Digest. 9 (7 and 8). July/August. P. 8. 